821.163.41.09-31 Станковић Б. https://doi.org/10.18485/kij.2020.67.1.3

ПРЕДРАГ Ж. ПЕТРОВИЋ *

Универзитет у Београду

Филолошки факултет
Оригинални научни рад

Примљен: 05.04.2020.

Прихваћен: 04.06.2020.

\title{
СТАНКОВИЋЕВ РОМАН О ЛЕПОТИ
}

\begin{abstract}
Нечиста крв уметнички је врхунац интересовања дотадашњег српског романа за судбину жена које више нису епизодни или споредни него главни ликови. Станковићево приповедање, као никад до тада у нашој прози, доводи у фокус питања еротике и сексуалности, односа тела и идентитета те нелагодности појединца у култури. Софка се у роману суочава не само са неминовном пролазношћу физичке лепоте и младости него и са универзалном неостварљивошћу жеља и снова, што ће бити велика тема српског модернистичког романа, поготову остварења Милоша Црњанског или Меше Селимовића. По томе колико су њен идентитет и самосвест битно одређени спознајом и доживљајем властитог тела као лепог и изузетног, Софка је јединствена јунакиња у нашој прози.
\end{abstract}

Кључне речи: лепота, роман, тело, еротика, сексуалност, приповедање.

\section{У сећање на професора Новииу Петковића}

Док посматра гротескно свадбено весеље у кући газда Марка, Софки, главној јунакињи романа Нечиста крв Борисава Станковића, чини се да је све то као у неким старим причама и песмама о украденој лепотици. Наратив се тада за тренутак измешта из једног, назовимо га реално могућег, нивоа фикционалности у други који припада домену архетипске имагинације а тиче се судбине лепоте коју хтонска бића воде из висине и светлости у доњи свет:

„И учини јој се, чисто као у причама и песмама, као да је она нека чувена лепотица, па одведена у кулу и тамо скривена. А ови Маркови, дању пландујући и кријући се, а ноћу склањајући се од месечине и ведрине, дуго путујући, пронашли је, и пошто кулу освојили, порушили, њу уграбили, и сада са њом, ето, овде стали да се одморе.” (Станковић 1985: $126)^{1}$

*pedja611@yahoo.com

${ }^{1}$ Све цитате из Нечисте крви наводићемо према овом издању са бројем странице у загради. 
Овај одломак речито упућује на то да је Станковићев роман, можда више од свега, посвећен феномену лепоте, њене судбине и страдања. То је оно што нас поводом овога дела, вероватно, највише узбуђује и потреса. ${ }^{2}$ Зашто лепа, сензуална, жена као објекат еротске жеље, у књижевности углавном мора да страда? То је питање које се може поставити већ поводом мита о Орфеју и Еуридици, својеврсног архетипа свеколике поезије. На њега су давани различити одговори а један од најпознатијих је онај у есеју „Филозофија композиције” Едгара Алана Поа, према коме је „смрт лепе жене неоспорно најпесничкији предмет на свету” (По 2006: 76) јер повезује две највеће људске и уметничке фасцинације: лепоту као најсилиније и најузвишеније задовољство, и смрт, као најтужније искуство са којим се човек суочава. Софка у Станковићевом роману не умире, али оно што је на крају сналази, када њена лепота копни а измучено тело пропада, горе је и од смрти: „И ништа се не деси. Још мање смрт да дође” (161).

И приповедач Андрићевог романа На Дрини ћуприја, коментаришући судбину Фате Авдагине, лепотице које се баца са моста у реку јер, као у народној балади, не жели да пође за недрагог, поменуће песме и приче које чувају сећања на лепа бића уздигнута до опасних висина:

\footnotetext{
„Одувек је код нас тако да по једна девојка у сваком нараштају уђе у причу и у песму својом лепотом, вредноћом и господством. Она је онда за тих неколико година циљ свих жеља и недостижан узор; на њеном имену се пали машта, око њега се расипа одушевљење мушкараца и плете завист жена. То су она изузетна бића које природа издвоји и уздигне до опасних висина." (Андрић 1990: 142) 3
}

Од античких времена познати су митови и трагедије о јунацима који страдају јер су се лепотом и гордошћу уздигли до опасних висина које, вољом богова, смртницима не припадају. То је добро знао и Лаза Костић када је писао трагедију Максим Црнојевић инспирисану нашом најдужом епском народном песмом. „У нашој народној поезији”, истиче Станислав Винавер, „Лаза је видео поезију најближу хеленским слутњама о лепоти; чак ту наша народна поезија и надмаша хеленску у понечем, у томе што сматра: да је лепота кобна" (Винавер 1963: 300). У четвртом поглављу Станковићевог романа, које је свакако кључно за разумевање Софкиног лика, она је представљена као изузетно биће, девојка свесна своје несвакидашње лепоте, толико да себе повремено доживљава као странца у варошком друштву - „она ништа са њима није имала заједничког. Све је за њу било то тако туђе и страно” (32). Издвојена од других и задовољна собом, она са висине, седећи на прозору, гордо посматра тај свет: „Јер, виша од свих и зато задовољна собом, особито том својом јединственом лепотом, она је

\footnotetext{
${ }^{2}$ Когнитивна наратологија и новија аналитичка естетика велику пажњу посвећују питању зашто нас толико потресају садржаји који су фикционални. „Како је могуће да нас потреса судбина Ане Карењине?" наслов је утицајне студије Колина Редфорда. Док читамо роман или гледамо позоришну представу, емоције су саставни део нашег естетског доживљаја иако унапред знамо да су сви приказани догађаји,махом,измишљени. Овај феномен, познат као парадокс фикције, један је од суштинских за разумевање статуса и природе књижевног дела. (В. о томе: Редфорд 2013)

${ }^{3} \mathrm{O}$ феномену женске лепоте у Андрићевој прози в. Стојановић 2003.
} 
равнодушно све то око себе посматрала" (29). Збивања у Нечистој крви не могу се, наравно, поредити са поетиком и заплетом античке трагедије, али Софкина гордост као да има нешто од хибриса, као прекорачења границе коју су богови одредили смртницима. ${ }^{4}$ Ипак, тешко да се њена злехуда судбина може разумети само на тај начин, као што се не може једноставно подвести ни под хришћанске категорије греха и казне. Али да се Софкина изузетна лепота указује као потенцијално кобна, не само по њу него и по друге, у роману је сугерисано опет једном сценом наглашене фолклорне имагинације. Након што побегне од куће, Томчи се, док ноћу јаше коња у шуми, учини како на реци, усред воде, види нагу и заносну вилу бродарицу која се купа и зове га к себи, желећи да га омађија:

„Била је иста она, Софка. Али, да га не би то омађијало и он се вратио натраг к њој, а највише из страха да не би и алат, од тоге се уплашио, цурукнуо и силом ка кући однео - он је сав по алату полегао. Рукама запушио му и очи и уши.” (158)

Ови архетипски моменти само су један од смисаоних нивоа разумевања Софкиног лика. Они остали морају се тражити у заплету, психолошкој мотивацији или социјалним и културолошким околностима варошког света који је обликован у роману. Али отворимо за тренутак могућност да постоје и разлози који се не тичу само логике романескне фикције него и они који припадају духу времена када је роман написан. Тумачећи Флоберову Госпођу Бовари Жак Рансијер потенцира управо те друге разлоге који објашњавају нужност одабраног расплета Флоберове приче. А тај расплет је морао бити баш такав зато што у преплету књижевности, демократије и медицине у француском друштву половине деветнаестог века, Ема није могла да преживи него је морала бити погубљена. „Зашто је било неопходно убити Ему Бовари?” - то је питање на које Рансијер тражи одговор, намерно изазивајући сваког читаоца Флоберовог романа, јер, као што знамо, главну јунакињу нико није убио, она је извршила самоубиство које је мотивисано низом узрочно-последичних догађаја и стања. Али поред тог унутрашњег сплета околности, Рансијера интересује и онај друштвени и политички заплет који је утицао на писца да својој јунакињи одреди баш такву судбину. „Према томе, потребно је поћи од следећег: Ема умире зато што је романописац Флобер одлучио да напише књигу о смрти једне жене" (Рансијер 2008: 54). Разлози који су га на то навели, тичу се првенствено новог статуса који је уметност и књижевност задобила у околностима развоја демократије у Француској половином деветнаестог столећа. Све то, на први поглед, нема много везе са контекстом настанка Станковићевог романа, али једна поетичка концепција их ипак повезује а то је естетицизам или ларпурлартизам као доминантна одлика европске и српске модерне. Софка целином свога бића припада лепоти и онога тренутка када та лепота постане предмет трговине и задовољавања статусних и материјалних интереса, односно када буде грубо сведена у оквире баналних овоземаљских односа, она неминовно пропада. Та пропаст лепоте у новим дру-

\footnotetext{
${ }^{4}$ „На Софки као да се обистинила стара легенда о освети богова који своје љубимце уздижу високо изнад осталих смртника а затим их бацају у провалију” (Деретић 1981: 218).
} 
штвеним и историјским околностима у исти мах упућује и на урушавање старе и богате културе чији је Софка последњи, величанствени изданак. Породична хроника јунакињиних предака отпочиње приповедачевом констатацијом о великој старини њихове куће: „Изгледа да откада је варош почела постојати, да је и та њихова кућа већ тада била ту" (Станковић 1985: 7). Софкина несрећа зато је више од индивидуалне трагедије, то је завршни чин нестајања једног света, његових обичаја и знамења. У томе се свакако може препознати траг натуралистичке поетике, утицајне у европској прози на измаку деветнаестог века. Већ је Скерлић упоредио почетак Нечисте крви са Золиним романима о Ругон-Макаровима, а томе бисмо данас додали и сагу о Буденброковима Томаса Мана, у којима је представљена „дегенерација једне богате куће где потомци плаћају раскошни и сладострасни живот старих" (Скерлић 1694: 188). Иако роман вишеструко превазилази ту, за то доба карактеристичну, тему, чини се да Софка није успела да избегне детерминистичку визију живота натуралистичке, у медицинском дискурсу утемељене, поетике која уоквирује роман:

„Али то њу није изненађивало. Све јој је било тако јасно. Све се, исто као некада, и сада понавља. Исто као што од оног њиховог хаџи-Трифуна њени почели да пропадају, тако, ево, и овде почиње од свекар јој, Марка, мужа Томче, и саме ње.” (162)

Важно је истаћи да је Нечиста крв уметнички врхунац интересовања дотадашњег српског романа за судбину жена, које нису више епизодни или споредни него главни ликови. Наиме, приметно је да како се деветнаести век ближио крају, тако су се учесталије појављивали романи који су у потпуности фокусирани на друштвену позицију жене. Најпре је објављена Патница (1888) Јакова Игњатовића. Прича о прељубници коју средина осуђује, окосница је овог амбициозно замишљеног друштвеног романа за који, због мелодраматичности и тенденциозности, ни критичари ни читаоци нису имали превише слуха. У то време јавља се и прва жена романописац у нашој књижевности, Драгиња Гавриловић, ауторка Девојачког романа (1889) о еманципованој јунакињи која жуди за браком из љубави. Убрзо се појавила и Сељанка (1893) Јанка Веселиновића, заснована на богатој етнографској грађи и биографском моделу који прати живот јунакиње од удаје до смрти. Женски ликови сложене социјално-психолошке мотивације изразити су у романима Светолика Ранковића а понајпре у Сеоској учитељици (1899). На почетку новог века Стеван Сремац објављује Зону Замфирову (1903), анегдотски заснован хумористички роман који је до данас остао једно од најбољих и најпопуларнијих остварења нашег реализма. Удаја чаршијске лепотице биће тема и Мајчине султаније (1906) Светозара Ћоровића али са трагичним расплетом јер, разочарана и несрећна, јунакиња умире на порођају. Нечиста крв са свим овим романима дели заједничку тему и то је управо удаја, коју приповедачи тога доба третирају како кључни догађај у животу жене. Ипак, за поетику српског романа на почетку прошлога века значајније су разлике између Станковићевог и наведених дела и оне би се могле свести на однос реалистичког и модернистичког дискурса. Индивидуалност, усамљеност, тело, интима - то су нове 
поетичке координате унутар којих се успоставља Станковићево приповедање а за њим и Андрићево, Црњансково и Растково.

Могло би се с пуним правом рећи да су у роману Нечиста крв приповедачки и тематски уписани неки од преломних момената српског друштва и културе на прелазу векова: историјски, везан за ослобађања југоисточне Србије од турске власти и њеног интегрисања у матицу; социјални, који се тиче пропасти старих и успона нових слојева друштва што изазива далекосежне промене у поретку културе; коначно, ту је поетички прелаз од натурализма ка импресионизму, односно модернизму, у приповедачком обликовању слике света и идентитета јунака. Коначно, изузетност романа Нечиста крв превазилази оквире књижевности зато се што се поводом овог дела може говорити и о конституисању модерног поимања индивидуалности и интиме почетком двадесетог века. Станковићево приповедање, као никад до тада у нашој прози, доводи у фокус еротику и сексуалност, однос тела и идентитета те нелагодност појединца у култури. Реч је заправо о низу културолошких, антрополошких и психолошких питања којима велику пажњу посвећују новији приступи у проучавању књижевности, од лакановске психоанализе, посткласичне наратологије, феминистичке критике до студија простора и екокритике. У том смислу, пажње је вредно да Станковић, у интервјуу Бранимиру Ћосићу у књизи Десет писаиа десет разговора, наглашава колико му је у приповедању било стало да избегне сваку конвенционалну „углађеност” и „пристојност”, односно да прекорачи неке до тада успостављене границе у српској књижевности. Критикујући Милитина Ускоковића који се у Дошљьацима служи „новинарским фразама” када приповеда о сексуалном чину, Станковић вели и ово:

„Има да се буде у таквим тренуцима или уметник или да одете у порнографију. Они који немају снаге или одлазе у порнографију или у стил. Код мене имате у Нечистој крви оно место са Софком и мутавком када му она узима руку и меће у своја недра. А је ли то порнографија?" (Ћосић 2002: 34)

Те особености приповедачког поступка у Нечистој крви које су у директној вези са јунакињином самосвешћу, телом и интимом, најбоље је уочио Новица Петковић истакавши да је Софка добила повлашћену позицију у наративној структури, што се не може упоредити са позицијом било ког књижевног лика до тада. Не само да су сва дешавања представљена из њене перспективе, односно свести, чулног и емотивног доживљаја, него је и „свест њена дигнута до равни на којој се роман као целина приповеда, доведена је у велику близину невидљивог приповедача” (Петковић 1988: 17). Тај нови однос „аутора и јунак у естетској активности" прозвођења приче (Бахтин 1991) формулисан је у једном од кључних исказа за разумевање како Софкиног лика тако и приповедања у роману: „Софка је од увек, откако памти за себе - знала све” (27). Дакле, уместо

${ }^{5}$ У програмском есеју „За слободни стих” (1922) Црњански оштро криткује конзервативни укус претежног дела читалачке публике која „нашег најјачег прозаисту, Станковића, сматра порнографом" (Црњански 1991: 9). 
свезнајућег приповедача сада имамо, условно речено, свезнајућу јунакињу. ${ }^{6}$ Ни избор њеног имена није случајан - Софка, као хипокористик од Софија (грч. $\Sigma o(i ́ \alpha)$, што значи мудрост или знање. Међутим, индикативно је да се наведена реченица налази на почетку четврте главе романа, оне која је у целини посвећена не само опису Софке него и њеној потреби да се предаје страственим уживањима у лепоти и чулним задовољавањима свога тела. Испитујући на које се начине тело конституише у приповедању, Питер Брукс, полазећи од Фројдових и Лаканових ставова, истиче да је епистемофилијски нагон, као жеља за знањем, у крајњем исходу повезан са примарном сексуалношћу, односно сексуалном радозналошћу и истраживањем властитог тела, што има вишеструки значај за разумевање идентитета књижевних јунака. „У модерном приповедању протагониста често чезне за телом, најчешће туђим али некад и властитим, и тело за њега представља коначно добро јер у себи, и по себи, садржи кључ задовољења, снаге и значења" (Брукс 1993: 8). Али не само у приповедању већ и у контексту културе и прозвођења значења, телесне сензације први су елементи сложеног мозаика симболичких структура, дискурзивних система и, коначно, самог поретка културе, за шта је Станковићев роман изузетан пример. Новији социолози и историчари приватног живота доказују колико је позиција тела и заштита приватности и интиме битно утицала на архитектуру, одевање, подизање деце, образовни систем и слично. Пратећи како се секс у модерно доба трансформише у дискурс и регулише читавом мрежом знања, анализа и прописа, Фуко наводи пример колеџа који су почели да се граде од осамнаестог века. Иако се на први поглед чини да организација тих институција нема никакве везе са телом или сексуалношћу, њихова архитектура, распоред учионица, спаваоница и дворишта упућује на то да је „питање секса ту непрестана преокупација. На њега су мислили градитељи, и то изричито" (Фуко 2006: 35). Нешто слично могло би се приметити у варошкој култури Станковићевог романа. Кључна збивања одвијају се у кућама ограђеним високом зидовима, иза капија ,јаких као град” (7). Софка може да се препусти страстима властитог тела у приватности породичног дома док преласком у кућу газда Марка, у простор који је за њу стран и не припада само њој, ту слободу и привилегију губи.

У четвртој глави Нечисте крви Софкин лик се успоставља кроз њену наглашену свест о хаџијском пореклу али, још више, и о властитој лепоти. Таква изузетна лепота не одликује ниједну другу варошку девојку као ни младића - „она је била уверена да никада, никада неће бити тога, неће се родити тај који би био

${ }^{6}$ У Нечистој крви преовлађује онај прелазни тип приповедања познат под именом доживљени говор или слободни индиректни говор који унутар нарације у трећем лицу преноси јунакове мисли. Теорија психолошког романа посветиће овом типу приповедња велику пажњу јер у њему види једну од могућности продора у свест и интиму јунака што је изузетно важно за одређење саме књижевности и њене особености у односу на друге облике писања. „Стварни свет постаје фикција тек када се разоткрије скривена страна људских бића која тај свет настањују,” истиче Дорит Кон и додаје: „Вероватно би се могла бранити теорија према којој се роман, у кружном (или спиралном) кретању, враћа својој унутрашњој матрици онда када његови јунаци постану хиперактивни, његов свет пренасељен а његова оријентација превише натуралистичка.” (Кон 1978: 9) 
раван и достојан ње; достојан и њене оволике лепоте а и саме ње, као Софке ефенди-Митине” (29). Ту је јунакиња, како у сопственом доживљају тако и у приповедачевом вредновању, уздигнута до оних опасних висина са којих ће пад бити понижавајући и трагичан. Али издвојена својом лепотом и гордошћу од других, Софка је у исти мах и усамљена, што је, као и Милићевићевом Беспућу или Исидориним Сапутницима, препознатљива одлика књижевних јунака новог века. Препуштена себи, првенствено свом телу и снажним чулним доживљајима, она жуди за другим бићем које би је разумело, утешило у тренуцима самоће и страха али и задовољило њене скривене еротске жеље. Док у реалистичкој прози ауторски приповедач има ексклузивно право да производи наративне ентитете, дотле у Нечистој крви ту улогу добија и „повлашћена” јунакиња. У тренуцима када је њено тело на врхунцу чулне раздржености и еротске пожуде, она осећа „како није она сама, једна Софка, већ као да је од две Софке. Једна Софка је сама она, а друга Софка је изван ње, ту око ње” (34). У суптилном односу између жудње и забране јунакињина имагинација не само да ствара двојницу са којом отпочиње узбудљиву еротску игру, него у исти мах, и своје тело доживљава као друго. Приповедач се смело упушта у опис оних тренутака када „машта пројектује тело у имагинарне сценарије испуњења, задовољства и моћи и назад до несвесних инфантилних извора" (Брукс 1993: 12). Софка се препушта еротској игри самозадовољавања тела али се при томе, ипак, „осећа као неки кривац” (34), слутећи да прелази границе које култура поставља, као што у том тренутку и Станковићево приповедање, изнијансирано и провокативно у исти мах, иде далеко изван оквира дотадашње српске прозе. ${ }^{7}$ Оно што Софкине еротске снове чини провокативним је чињеница да њене „најтајније, најслађе и најлуђе жеље, чежње и страсти" (34) испуњава имагинарна двојница, дакле жена, а не некакав замишљени мушкарац. Из психоаналитичке визуре, то је карактеристични облик аутоеротизма или нарцистичког стадијума сексуалности у којем постоји „фиксација либида за сопствено тело и сопствену особу” (Фројд 1969: 388). Занимљиво је да се у истом поглављу јунакиња препушта и сновима о брачној срећи у којима се јавља идеализована слика младожење достојног њене лепоте. Иако је завршница тих снова у знаку кратког препуштања необузданој сексуалности, они су, ипак, ближи конвенцијама о брачној заједници, снажном мушкарцу, богато намештеној кући и лепој одећи. Управо у томе се види сложена динамика Софкиних еротских жеља које се обликују између слободе и забране, скривеног и пожељног, интимног и јавног. Потпуно испуњење скривених фантазија јунакиња има замишљајући однос са женом, својом двојницом, која једина

${ }^{7}$ У Историји сексуалности Мишел Фуко истиче да се до новијег доба самозадовољавање „редовно повезивало са маштаријама и опасностима које човеку прете од његове маште; на мастурбацију се гледа као на главни вид неприродног чулног наслађивања које су људи измислили да би прекорачили границе које су им биле прописане” (Фуко 1988: 157). Борба против еротских слика, у свести ли ван ње, била је „услов и јемство исправног владања у полном животу и представљаће један од најпостојанијих видова полне етике” (Фуко 1988: 155-156). 
може да је схвати, утеши и задовољи. Мушкарац у Софкиној имагинацији остаје у друштвено прихватљивој и очекиваној улози брачног сапутника.

Фигура мушкарца јавиће се у четвртом поглављу још два пута. Након сневања о брачној срећи Софка би „чисто како какав мушкарац, са толико страшћу почела да посматра своје праве, крупне дојке” (36). Она се уживљава у позицију мушкараца који се диви њеном телу, чиме се у приповедању, за тренутак, отвара интригантна могућност измене родне перспективе посматрања која се одиграва у свести и доживљају саме јунакиње. Софка након тог пожели да заиста „осети мушку руку на себи” (36), што се одиграва у гротескној сцени са мутавим слугом Ванком. Осетивши само бол у том грубом додиру, Софка Ванка брзо одбацује, ужаснута телесним додиром који је далеко од испуњења оног чулног ужитка који је осетила у еротским сневањима. Могло би се рећи да је четврта глава романа изведена пажљивом градацијом која се одвија од еротске жеље до сексуалног хтења, у оном значењу које им даје Михаил Епштејн, наглашавајући њихову, у новије време занемарену, разлику - док сфери еротског припадају „жеља и уживање, забрана и завођење, страст и игра" као делови суптилних духовно-телесних и психокултурних односа, дотле се сексуалност тиче „биолошке, физиолошке и психофизиолошке природе полних нагона" (Епштејн 2009: 95-96). Сцена са мутавим Ванком свој пуни смисао добија у завршници романа када, након Томчиних садистичких мучења, Софка, раздражена и пијана, проводи ноћ са слугама. „И зато су онда сви момци што би служили код ње морали увек бити глувонеми" (161). У распону између те две сцене виде се ужасавајуће размере јунакињине пропасти. Док се на почетку романа, горда и самосвесна, грози свега грубог и ниског, дотле се на крају, распамећена и измучена, она сасвим предаје тој ружној стварности, желећи да себе, како вели приповедач, „сасвим умртви", надајући се још само смрти као избављењу.

Оно што јунакиња доживљава у претежном делу четврте главе романа могло би се подвести под различите облике сублимације или редирекције еротске жеље, чему је психоанализа посветила велику пажњу. У томе важно место има и Софкина обузетост не само сопственим телом него и другом облицима лепоте од којих је посебно значајан вез, као креативна активност којој се она страствено и посвећено препушта у тренуцима када је обузме немир:

„Сва се унесе у посао. Целог дана не дижући главе ради. Мати једва би је одвојила да руча и вечера. И што би се посао све више и јаче испод њених руку оцртавао, појављивао, слике се као живе издизале - а тај вез и паре биле су тако тешке, да друга на њеном месту тек ако би месецима могла да уђе у њ - она би све више и више у то уносила и одмах би се почела осећати другачије. Мирније спава. Ујутру свежија.” (33-34)

И у самој завршници романа видимо је како расплиће замршену пређу, седа за разбој и тка или машицама шара по пепелу угашеног огњишта. Иако Софка не говори много и вероватно не зна да пише, ипак би се могло рећи да она има своје писмо. То су управо те „тешке паре” њених везова или знаци исписани „меким и нежним потезима” по мрком пепелу, као њеном руком обликована и материјализована сведочанства интимне драме. Од тих нежно исписаних шара 
у пепелу, као симбола оног што је остало од негдашње лепоте, један могући уметнички и смисаони континуитет модерног српског романа одвео би нас до зиданице на песку у Селимовићевом Дервишу и смрти или до горког стеченог сазнања Кишовог Пешчаника о материјализованом писму живота као „малој, тужној, ништавној људској победи над големим, вечним, божанским ништавилом" (Киш 2006: 266).

Представљена као биће изузетне лепоте, сензуалности и самосвести, Софка ће доживети драстичан пад удајом за Томчу, дечака из богате сеоске породице недостојне хаџијског статуса и угледа ефенди-Митиног дома. Међутим, ова, и за то време непримерена удаја, која постаје централни догађај романа, није мотивисана само социјалним разлозима, односно потребом да се сачува кућу од даље пропасти. Након драматичног разговора са оцем, Софка, у једанаестој глави романа, у низу преиспитивања покушава да се сама пред собом оправда, да пронађе довољно јаке разлоге за удају. Она је свесна да мора да се „жртвује ради њих, да њих избави од сиротње и беде" (78). То жртвовање зарад опстанка породичног дома биће истакнуто у призору након Софкиног повратка из амама. Прилазећи кући, која је до тада за њу била простор слободе и ноћних препуштања ужицима властитог тела, она најпре види фењере „као два црвена страшна ока”, затим осети мирис нечега „покојног, мртвачког” и потом опази нове црвене ћерамиде на крову за које јој се учини „као да су од њеног меса, од ње саме” (103). Овде се опет активира архетипски наративни модус који сугерише да су Софкино тело и лепота жртвовани, узидани у саму кућу. Јунакиња је свесна да „својом жртвом толико убија себе” (78) јер полази не само за недрагога него за, готово, дете. Зато жртвовање за породицу, ма колико плементито било, није за Софку довољно јак разлог да пристане на удају. Коначно и задовољавајуће оправдање она налази у могућности да тај чин буде нова, врхунска потврда њене изузетности: „Толиком жртвом сигурно ће запрепастити и задивити све. И у очима свих, не само што ће остати онаква, него ће све већа бивати и дизати се а не можда, као што је свет мислио, и надао се, па сигурно и чекао, када ће она, већ једном пасти, поклекнути" (78). Њена судбина тако постаје својеврсна трагедија самообмане о властитој изузетности у постојећим животним околностима. Јер прелазак из високе, варошке културе у периферну, сеоску средину у којој ће њене лепота бити спуштена на овоземаљску, баналну разину, биће само у првом тренутку нешто изузетно и до тада невиђено, да би се врло брзо претворио у драстичан пад.

Нечиста крв развија визију лепоте и виталистичке енергије чија се супстанца троши и нестаје у баналности живота, а поготову на друштвеној позорници којом владају страст и материјални интереси. Софка се у роману не суочава само са неминовном пролазношћу физичке лепоте и младости него и са универзалном неостварљивошћу жеља и снова, што ће бити велика тема српског модернистичког романа, поготову остварења Милоша Црњанског или Меше Селимовића. То њено сазнање изражено је исказом који је би се могао назвати лирским, односно елегичним језгром романа али и Станковићевог опуса у цели- 
ни. Док се у амаму припрема за венчање, Софка слути да је то њена симболична смрт. Не жали она толико за дотадашњим животом колико за својим неиспуњеним сном о срећи, за оним тајним жељама и љубавима које ће заувек остати сахрањене у њеној души: „Све што је душа волела, за чим је жеднела, и ако не на јави, оно бар у потају неговала, све сутра иде, одваја се, откида...” (100). Поводом Сапутника Исидоре Секулић Дучић ће записати афористички исказ који би се, можда у још већој мери, могао односити и на Станковићеву јунакињу: то „није жаљење за животом који је прошао него за оним што никада није ни дошао” (Дучић 1969: 101).

По томе колико су њен идентитет и самосвест битно одређени спознајом и доживљајем властитог тела као лепог и изузетног, Софка је јединствена јунакиња у нашој прози. Самосвест књижевних ликова биће у модернизму најчешће рефлексивног типа, као што је то случај већ у Сапутнициима, објављеним коју годину касније. То, међутим, није једноставна дихотомија тела и мисли или тела и језика јер, како истиче Жил Делез, наше поимање живота одређено је положајима и ставовима тела, и то у много већој мери него што то картезијански ум хоће да призна. Модерна уметност, репрезентован делима као што су роман Уликс Џејмса Џојса, скулптура Пољубаи Константина Бранкузија или филм До последњег даха Жан-Лика Годара, показују да тело није препрека коју мисао одваја од ње саме или коју мисао треба да превазиђе и одбаци. „Напротив, тело је оно у шта мисао урања или треба да урони како би досегла немисливо, то јест живот. Није реч о томе да тело мисли, већ оно тврдоглаво и упорно нагони на промишљање, и то оног што измиче промишљању, што се крије од мисли, а то је живот" (Делез 2010: 239). По томе како се из стања и доживљаја тела конституише идентитет, Софка је претходница неких ликова у роману Дан шести Растка Петровића али и Вука Исковича у Сеобама Милоша Црњанског. Облачећи се за војну смотру у Печују, у другој глави романа, Вук гледа свој одраз у огледалу. За разлику од Софкиног, његово тешко и подбуло тело, једва увучено у китњасту официрску униформу, гротескно је. Ипак, и Исаковичева самосвест почиње иницијално да се уобличава управо посматрањем свог тела. Али за разлику од Станковићеве јунакиње, он се од свог физичког изгледа отуђује и доживљава га друго биће, странца: „Навлачећи своје црвене чохе, њему се потпуно учини да се то облачи неко други, а не он, и да ће то неко други сада изаћи накинђурен, из те собе, а не он” (Црњански 1981: 26). То дистанцирње од тела које по туђој вољи учествује у бесмисленим дешавањима на историјској позорници, постепено ће генерисати „другог” Вука Исковича, меланхоличног и ћутљивог, који се препушта суматраистичким визијама звезданог неба. И Софка има поглед уперен ка небу. Након што је сазнала да је испрошена, она ће последњи пут имати визију идеалног мушкарца достојног ње: „тамо на небу, међ облацима, одмах би тако јасно и истински видела како се оцртава и издиже он. Јак висок, са јаким рукама. И онда он почиње к њој да долази" (92). Та визија на небу, издигнута из оквира овоземаљске спутаности и безизлаза, биће последњи Софкин сан о лепоти и срећи. 
Тело, наравно, увек фигурира у књижевности али са различитим степеном експлицитности. Ниједан наш аутор, до појаве Нечисте крви, није посветио толику пажњу телу ${ }^{8}$. Софкино тело у роману није само објект дескрипције него и агенс, покретач наративне и еротске жеље, те као такво оно суштински утиче на поетичко обликовање одређених приповедачких, композиционих и стилских поступака. Ти књижевни поступци, можда више од свега, теже да јунакињино тело и самосвест изразе, обухвате и уведу у домен језика. Док Софка није стасала у чувену лепотицу и док још није конституисана њена, из телесног самоосећања произашла, самосвест, дотле је у роману наглашенија улога хроничарског, ауторског приповедача. Али чим се, од четвртог поглавања, њено тело успостави као изузетно, Софкини чулни доживљаји и знање долазе у наративни фокус, односно њена тачка гледишта постаје доминантни извор приче, а уместо хроничара, приповедач постаје „скривени редитељ романескне радње”. Тим речима је Зола назвао наратора Флоберове Госпође Бовари, истакавши да је „писцу успијело чудо, да га потпуно нестане а да се посвуда осјећа његова велика умјетност" (Зола 1948: 20). Слично чудо, засновано на суптилним модулацијама тачке гледишта, остварено је и у Нечистој крви. Међутим, како Софкино тело копни и лепота нестаје, тако је опет наглашенија позиција ауторског приповедача. При самом крају романа он ће се директно, у презенту, обратити читаоцу и позвати га да буде могући сведок Софкиног трагичног краја: „Нећете је никада видети да једе. Готово никад ништа" (164). Када је од негдашње лепоте остала само сенка и траг у пепелу, нема више мотива за даље приповедање, нема оне еротске жеље која је водила причу и зато се она ту и завршава. Не само у нарацији него и на плану читања ,жудња за спознајом тела и његових тајни постаје жеља да се овлада симболичким системима текста, његових значења, задовољства и истинског стварања смисла" (Брукс 1993: 14). У романескној структури Софкино тело је онај величанствени уметнички знак око кога се окупљају различите смисаоне равни приче и у којем читалац жели да осети задовољство у тексту. ${ }^{9}$

Ако је трагична судбина лепоте одређујућа тема Станковићевог романа која пресудно утиче на поетичко генерисање приповедачких и композиционих поступака, поставља се питање има ли лепоте и у самом језику и стилу Нечисте крви и то не као некаквог реторичког или орнаменталног додатка него као онтолошког својства самог приповедања. Баш у тим аспектима вредновања многи критичари налазили су могуће слабости не само овог остварења него и Станковићеве прозе у целини. Називајући га „романом од велике вредности” Скерлић, ипак жали што „форма није на висини садржаја” због честих „спотицања у стилу”

${ }^{8}$ У новије време о Софкином телу у Нечистој крви опширно је писала Наташа Ивковић (Ивковић 2011).

9 Док Барт размишља о могућности да текст буде „фигура, анаграм нашег еротског тела” (Барт 2010: 108), Епштејн потенцира разлику између тела и плоти која је аналогна односу фабуле и сижеа. „Тело је фабула додиривања, а плот - његов сиже, односно претварање опиљивог тела у оно што нас и само додирује, под чијим се дејством налазимо, претварање у тај редослед догађаја: додиривања, припајања, интиме и премештања, који образују сиже уживања" (Епштејн 2009: 121). 
(Скерлић 1964: 189). А о том стилу критичар је писао и поводом Божјих људи: „Стил је лабав, немаран, без везе, са честим понављањима, такав да све изгледа као да је од беде или преко колена рађено" (Скерлић 1964: 186). Сличне ће бити оцене Бранка Лазаревића а неколико деценија касније Јован Деретић поновиће да је Нечиста крв једно од најзначајнијих дела наше прозе „упркос очигледним слабостима у композицији и језику” (Деретић 1981: 221). Тек ће анализе Новице Петковића убедљиво доказати да се овде не ради ни о каквим недостацима него о новом типу композиције засноване на поступцима симетричног „темпоралног уоквирења романа" (Петковић 1988: 117), који ће од тада бити карактеристичан за српски модернистичи роман, од Сеоба преко Травничке хронике и Проклете авлије до Дервита и смрти. Ни специфичности Станковићевог језика и стила „не могу се посматрати само као грешке, него превасходно као стилогене синтаксичке фигуре” (Петковић 1988: 54-55) које су у функцији изражавања интимне драме јунака и њихових сложених психичких стања. Настајала ван оквира београдског стила, који се у доба модерне легитимише као стандардни књижевни језик, Станковићева проза, слично као и Дисова поезије, потврђује да језик књижевног дела увек представља поетички мотивисану модификацију и одступање од стандардне норме, што ће бити препознатљиво обележеје низа српских модерниста - Милоша Црњанског, Растка Петровића, Момчила Настасијевића или Станислава Винавера.

Данас би, дакле, с пуним правом могли да кажемо да је Станковић имао изузетну артистичку свест о романескној форми. Радећи на тексту више од десет година, што је у то време било прилично неуобичајено, он је желео да приповедање, композицију и језик у што већој мери саобрази интими, самосвести и идентитету главне јунакиње. Међутим, ауторово промишљање приповедачких поступака узимало је у обзир још један важан моменат књижевног дела и његове рецепције, што се види у коментару уз друго издање Нечисте крви 1917. године. Бранећи се од критика о слабој композицији и „згужваном” епилогу књиге Станковић објашњава зашто у завршном делу романа, након сцена свадбе у газда-Марковој кући, приповедање постаје све фрагментарније а протицање времена брже: „(...) нисам хтео да читалац почне осећати писца, као што сам ја, код толико њих, осећао при крају романа. А и због тога, да не кажем све читаоцу већ да би он сам и даље мислио према својој умној развијености" (223). Није ли оваквим ставом да у структуру романа уведе и позицију читаоца који би, без наглашених интервенција приповедача, својом имагинацијом, или „умном развијеношћу”, повезао фрагменте у могућу смисаону целину, Станковић антиципирао неке од важних тенденција модерне књижевности и њеног тумачења? Ако је почетак двадесетог века обележен напором овог аутора да активира улогу читаоца у сазнајном процесу и естетском доживљају књижевног дела, завршетак тога века је у знаку тријумфа такве поетичке концепције. Романи Милорада Павића биће у потпуности засновани на способности читаоца да сам себи крчи пут кроз мапу текста при чему ће се садржина и облик мењати у зависности од тога која стратегија читања је одабрана. Али при томе је јасно да „ко хоће да мења начин 
читања једног романа, мора да мења начин писања" (Павић 2005: 19). Тога је, на себи својствен начин,био свестан и Борисав Станковић. Не желећи да његов приповедач „читаоцу каже све” он је изашао из оквира реалистичке наративне парадигме и отворио поетичке хоризонте слутње, неизвесности и тишине, у којима препознајемо одређујућа својства модернистичке епохе у нашој књижевности.

\section{ИЗВОРИ}

Андрић 1990: И. Андрић, На Дрини ћуприја, Београд: БИГЗ.

Киш 2006: D. Kiš, Peščanik, Beograd: Prosveta.

Станковић 1985: Б. Станковић, Нечиста крв, Београд: Просвета.

Црњански 1981: М. Црњански, Сеобе, Београд: Нолит.

\section{ЛИТЕРАТУРА}

Барт 2010: Р. Барт, Задовољство у тексту, прев. Ј. Аћин, Београд: Службени гласник.

Бахтин 1991: M. Bahtin, Autor i junak u estetskoj aktivnosti, prev. A. Badnjarević, Novi Sad: Bratstvo-jedinstvo.

Брукс 1993: P. Brooks, Body Work: Objects of Desire in Modern Narrative, Cambridge: Harvard University Press.

Винавер 1963: S. Vinaver, Zanosi i prkosi Laze Kostića, Novi Sad: Forum.

Делез 2010: Ž. Delez, Film 2: Slika-vreme, prev. A. Jovanović, Beograd: Filmski centar Srbije.

Деретић 1981: Ј. Деретић, Српски роман 1800-1950, Београд: Нолит.

Дучић 1969: Ј. Дучић, Моји сапутници, Сарајево-Београд: Свјетлост-Просвета.

Епштејн 2009: М. Епштејн, Филозофија тела, прев. Р. Мечанин, Београд: Геопоетика.

Зола 1948: E. Zola, Gustave Flaubert, prev. L. Šarić, Zagreb: Nakladni zavod Hrvatske.

Ивковић 2011: Н. Ивковић, Тело у роману Нечиста крв Борисава Станковића, Зборник Матице српске за књижевност и језик, књ. 59, св. 1.

Кон 1978: D. Cohn, Transparent Minds: Narrative Modes For Presenting Consciousness in Fiction, New Jersey: Princeton University Press.

Павић 2005: М. Павић, Роман као држава, Београд: Плато.

Петковић 1988: Н. Петковић, „Софкин силазак”, Два српска романа, Београд: Народна књига. 
Рансијер 2008: Ž. Ransijer, Politika književnosti, prev. M. Drča, Novi Sad: Adresa.

Редфорд 2013: K. Redford, Kako je moguće da nas potresa sudbina Ane Karenjine?, Paradoksi fikcije, prev. A. Kostić, Beograd: Fedon.

Скерлић 1964: Ј. Скерлић, Писци и књиге, књ. 5, Београд: Просвета.

Стојановић 2003: Д. Стојановић, Лепа биће Иве Андрића, Подгорица: ЦИД.

Ћосић 2002: Б. Ћосић, Десет писаиа - десет разговора, Бор: Народна библиотека.

Фројд 1969: S. Frojd, Uvod и psihoanalizu, prev. B. Lorenc, Novi Sad: Matica srpska.

Фуко 1988: M. Fuko, Istorija seksualnosti, knj. 3, prev. B. Jelić, Beograd: Prosveta.

Фуко 2006: M. Fuko, Volja za znanjem, prev. J. Stakić, Beograd: Karpos.

Црњански 1991: М. Црњански, Есеји и прикази, Нови Сад: Књижевна заједница.

Predrag Ž. Petrović

STANKOVIĆ'S NOVEL ABOUT BEAUTY

Summary

Borisav Stanković's novel Nečista krv is the artistic peak of the Serbian novel's interest in the fate of women who are no longer episodic or supporting but the main characters. Stanković's narration, as never before in Serbian prose, focuses on the issues of eroticism and sexuality, the relationship between body and identity, and the discomfort of the individual in culture. Sofka, the heroine of the novel, is a unique literary character in terms of how much her identity and self-consciousness are significantly determined by the knowledge and experience of her own body as beautiful and exceptional.

Keywords: beauty, novel, body, erotic, sexuality, narration. 